\section{Growth of Poinsettia as Affected by Cultivar, Thinning, and Pot Size}

\author{
Smiljana Goreta ${ }^{1,2}$, Kristina Batelja ${ }^{1}$, and Slavko Perica ${ }^{1}$
}

\begin{abstract}
AdDITIONAL INDEX wORDs. dry weight, Euphorbia pulcherrima, number of shoots, plant diameter, plant height, leaf area, pruning

SUMMARY. The effect of thinning to three, four, five, or six lateral shoots on the growth parameters of five differently colored poinsettia (Euphorbia pulcherrima) cultivars ('Christmas Star', 'Christmas Feelings', 'Cortez Candy', 'Marble Star', and 'Primero Roso') was studied by consecutive measurements of growth from September to December. In a separate experiment, the effect of pot size $(13-, 15-$, or $18-\mathrm{cm}$ diameter) on growth of 'Christmas Star' was studied. Cultivars responded similarly to thinning, but during the growing season, apparent differences in vegetative growth parameters between cultivars were observed, with 'Primero Roso' evaluated as the most vigorous. At the single-shoot level, the increased number of lateral shoots decreased the number of nodes at the beginning and the stem diameter at the end of the experiment. Leaf area, dry weight of stems, and total plant weight increased as the number of laterals increased at the end of experiment. The most distinctive canopy attribute in this study was the bract color because, according to customer evaluation, significant differences in visual appearance among tested cultivars were observed only for that trait. Pot size differentially affected the vegetative growth parameters of poinsettia 'Christmas Star'. Increasing pot size from a 13- to $18-\mathrm{cm}$ diameter resulted in an increase of plant canopy diameter, stem diameter, and the number of nodes on lateral shoots. There were no other substantial benefits on the measured growth parameters that could justify the use of pots larger than a $13-\mathrm{cm}$ diameter for a poinsettia crop established at the beginning of September.
\end{abstract}

$\mathrm{P}$ oinsettia is one of the most economically valuable horticultural plants in the world (Clifford et al., 2004). The greenhouse production of colorful (red, mottled red, white and red, and white) poinsettias is usually scheduled for sale during December (Kannangara and Hansson, 1998). Production is focused on a fast-growing, compact pot plant that retains its leaves and bracts under the less-than-favorable postharvest conditions found in households (Black and Schoellhorn, 2002).

Depending on market demands, poinsettia can be grown without pinching to produce single-stem plants (Fisher et al., 1996) or can be pinched (apical meristem removed) to promote the growth of lateral shoots to produce compact plants (Berghage et al., 1989; Black and Schoellhorn, 2002). Plants are usually pinched at five to seven nodes to produce five or more lateral shoots (Faust and Heins, 1996). Plants pinched to have more lateral shoots may have fewer developed shoots that are more prone to stem breakage (Kuehny et al., 2000). In poinsettia, the branching capacity after pinching is cultivar-related and there are two main groups of cultivars: free-branching and restricted branching (Faust and Heins, 1996). The factor contributing to development of axillary shoots in free-branching cultivars was identified to be an unculturable phytoplasma (Lee et al., 1997). In free-branching cultivars, thinning of surplus shoots could be an additional procedure to control growth and to achieve crop uniformity.

Compensatory responses of plants to shoot removal by pruning or by herbivores may involve an enhanced vigor of remaining shoots (Naor et al., 2002), an increase of leaf assimilation rate, or an alteration of growth patterns to favor leaf area (Thomas et al., 2006). The manipulation of the sink-source ratio by removing vegetative or generative organs is used in vegetable and ornamental production to control growth and yield (Heuvelink and Buiskool, 1995; Jovicich et al., 1999). The possibility of controlling poinsettia growth throughout sink limitation has not been extensively studied, and there is a possibility that cultivars might respond differentially.

In greenhouse production, growers are interested in the optimal utilization of available space and at the same time the maintenance of quality of the plants produced. This can be achieved by increasing the plant density per area or by growing plants in smaller pots. The influence of pot size on growth and development depends on the species and even on the cultivar within the species (Nesmith and Duval, 1998). van Iersel (1997) has found that growth rate of salvia (Salvia splendens) plants was positively correlated with pot volume, and the differences among pots increased throughout growing period. Increase in pot volume positively affected the dry weight of shoots and roots in hydrangea (Hydrangea macrophylla) and petunia (Petunia Xbybrida) (Haver and Schuch, 2001; Yeh and Chiang, 2001) and the height of sunflower (Helianthus annuus) plants (Pallez et al., 2002). Pot volume affects the amount of available water and nutrients, but it appears that root restriction imposed in smaller pots reduces

\footnotetext{
The authors thank Marija Bilic and Jela Filkovic for their valuable technical help, and the Croatian Ministry of Science, Education and Sports (Grant no. TP_01/0091_01) for partial funding of this study. Mention of a trademark, proprietary product, or vendor does not constitute a guarantee or warranty of the product and does not imply its approval to the exclusion of other products or vendors that also may be suitable.

${ }^{1}$ Institute for Adriatic Crops, Put Duilova 11, 21000 Split, Croatia

${ }^{2}$ Corresponding author. E-mail: smilja@krs.hr.
}

\begin{tabular}{llll}
\hline $\begin{array}{l}\text { Units } \\
\text { To convert U.S. to SI, } \\
\text { multiply by }\end{array}$ & U.S. unit & SI unit & $\begin{array}{l}\text { To convert SI to U.S., } \\
\text { multiply by }\end{array}$ \\
\hline 0.0929 & $\mathrm{ft}^{2}$ & $\mathrm{~m}^{2}$ & 10.7639 \\
3.7854 & $\mathrm{gal}$ & $\mathrm{L}$ & 0.2642 \\
2.54 & inch $(\mathrm{es})$ & $\mathrm{cm}$ & 0.3937 \\
25.4 & inch(es & $\mathrm{mm}$ & 0.0394 \\
6.4516 & inch & $\mathrm{cm}$ & 0.1550 \\
1 & $\mathrm{mmho} / \mathrm{cm}$ & $\mathrm{dS} \cdot \mathrm{m}^{-1}$ & 1 \\
28.3495 & $\mathrm{oz}$ & $\mathrm{g}$ & 0.0353 \\
1 & $\mathrm{ppm}$ & $\mathrm{mg} \cdot \mathrm{L}^{-1}$ & 1
\end{tabular}


growth, regardless of nutrient and water availability (Haver and Schuch, 2001; Nesmith and Duval, 1998; van Iersel, 1997). There is a lack of data related to the effect of pot size on growth of poinsettia. Ecke and Matkin (1971) suggested the use of pots ranging from 10 to $18 \mathrm{~cm}$ in diameter for poinsettia cultivation, depending on the time when the crop is established in the final pot.

The present studies were conducted to determine the effect of thinning to three, four, five, or six lateral shoots (laterals) on the vegetative growth of five poinsettia cultivars and to examine the effect of three pot volumes on the vegetative growth of 'Christmas Star'.

\section{Materials and methods Cultivars and number of lateral shoots (Expt. 1)}

Treatments AND growing CONDITIONS. The poinsettia plants were grown in a glass greenhouse located in Split, in the Mediterranean area (lat. $43^{\circ} 31^{\prime} \mathrm{N}$, long. $16^{\circ} 25^{\prime} \mathrm{E}$ ) under a natural photoperiod. Vegetatively propagated rooted cuttings were planted in $0.9-\mathrm{L}$ pots $(13-\mathrm{cm}$ diameter) and each plant was pinched at seven nodes on 10 Aug. At the end of August (30 Aug.), all cultivars were transplanted into $1.5-\mathrm{L}$ pots $(15 \mathrm{~cm}$ diameter) filled with peat-based organic substrate (Type 4; Gebr Brill Substrate, GmbH \& Co. KG, Georgsdorf, Germany) blended with perlite (Agrilit 3; Perlite Italiana, Milan, Italy) at a 3:1 (by volume) ratio.

The experiment was a factorial combination of five poinsettia cultivars, thinned by hand to three, four, five, or six shoots by removing weakly developed laterals at the end of August. The study included three red cultivars ('Christmas Star', 'Primero Roso', and 'Christmas Feelings'), one pink ('Cortez Candy'), and one marble cultivar ('Marble Star') obtained from a commercial producer (Selecta Klemm, GmbH \& Co. KG, Stuttgart, Germany).

Plants were grown on benches at $30-\times 30-\mathrm{cm}$ spacing (density of 11 plants $/ \mathrm{m}^{2}$ ) and were irrigated with a nutrient solution $[\mathrm{pH} 5.5$, electrical conductivity (EC) $\left.1.7 \mathrm{dS} \cdot \mathrm{m}^{-1}\right]$ recommended for cultivation of poinsettia in organic substrate, which contained the following nutrients (in $\mathrm{mg} \cdot \mathrm{L}^{-1}$ ):
183 nitrogen $(\mathrm{N}), 212$ potassium $(\mathrm{K})$, 156 calcium (Ca), 24 magnesium $(\mathrm{Mg}), 32$ sulphate $(\mathrm{S}), 33$ phosphorus $(\mathrm{P}), 24$ magnesium $(\mathrm{Mg}), 1.35$ iron (Fe), 1.69 manganese $(\mathrm{Mn}), 0.8$ zinc $(\mathrm{Zn}), 1.24$ borate $(\mathrm{B}), 0.12$ copper $(\mathrm{Cu}), 0.12$ molybdate (Mo) (Sonneveld, 1989). The nutrient solution was delivered via drip system with four outlet emitters of $3 \mathrm{~L} \cdot \mathrm{h}^{-1}$ capacity (Toro Co., El Cajon, CA) with one spigot placed in each pot. The irrigation rate depended on the size of the plant and the environmental conditions in the greenhouse. The amount of applied nutrient solution ranged from 0.15 to $0.45 \mathrm{~L}$ per plant per day with a leaching fraction of $15 \%$ to $20 \%$. The nutrient solution was provided until 20 Nov. and thereafter plants were irrigated with water adjusted to $\mathrm{pH} 5.5$ until the end of experiment. This is the recommended practice to extend the postharvest life of the plants and to prevent soluble salts injury to the bracts (Cox, 2000). The growth retardants for height control were applied as a drench to previously irrigated pots at 16 Sept., and at 7 and 27 Oct.

Plant growth measurements. Plant height (from the substrate surface to the top of the longest vertical lateral shoot), plant canopy diameter (the average of two measurements taken at the widest and shortest diameter), and main stem diameter (at the median position of the main stem) were measured on four plants per experimental unit. The most developed lateral shoot on each plant was marked for measurements of the shoot stem length, diameter (at the median part of third internode), and the number of nodes. Four measurements were carried out from September through December, in 4-week intervals.

At the beginning of December (5-8 Dec.), when at least $50 \%$ of plants of each cultivar reached anthesis, six plants per experimental unit were cut at the substrate level and separated into stems and leaves. The area of green and colored (bracts) leaves was separately measured using a leaf area meter (LI-3000; LICOR, Lincoln, NE). Leaves, bracts, and stems were air-dried and weighed.

A small-scale consumer preference survey was conducted at the end of the experiment. Thirty colleagues from our institute, of which $57 \%$ were women and $43 \%$ were men with an age ranged of 28 to 60 years, were asked to participate as evaluators. Three plants of each cultivar thinned to six lateral shoots were chosen and randomly arranged. Participants were asked to rate all plants (on a scale from 1 to 5 where $1=$ not satisfactory and $5=$ excellent) on each of the following attributes: color, plant height and canopy diameter, inflorescence number, ratio of leaves to bracts, and general impression.

Statistical analysis. The experimental design consisted of a completely randomized $(5 \times 4)$ factorial design, with five cultivars, four levels of lateral shoots, three replications, and 10 plants as an experimental unit. All data were subjected to analysis of variance (ANOVA) using PROC GLM of SAS (version 6; SAS Institute, Cary, NC) to determine the difference between cultivars and number of laterals, as well as the presence of any interaction. Measurements of plant growth, taken on the same plant or lateral shoot from September through December, were analyzed by repeated-measures ANOVA, with the date of measurement as a repeated factor. Interaction was found between the date of measurement and the cultivar for all observed parameters; therefore, data were analyzed separately for each date. Mean separation for the main effect of cultivar was performed by the Fisher's protected least significant difference test at $P \leq 0.05$, whereas the effect of shoot number was analyzed by linear and quadratic polynomials. Because quadratic polynomials were nonsignificant for observed parameters, only linear effects were reported.

\section{Pot size (Expt. 2)}

At 25 Aug., 'Christmas Star' plants were transplanted into three pot sizes: $0.9,1.5$, and $3.4 \mathrm{~L}$ (13-, 15-, or 18-cm diameter and 9.5-, $11.5^{-}$, or $16 \mathrm{~cm}$ tall, respectively). The origin of the plant material, growing conditions, and plant culture were comparable as stated for Expt. 1. We applied the same retardants at the same dates as in Expt. 1, except that the amount of retardant solution delivered depended on the pot diameter. The growth measurements were the same as described in Expt. 1. The experiment was set up as a completely randomized design with three replications, and data were analyzed as 
single repeated-measures ANOVA (pot sizes) with the date of measurement as a repeated factor. The effect of pot size within each date was analyzed by linear polynomials.

\section{Results and discussion}

Cultivars and Number of LATERAL SHOOTS (EXPT. 1). The lateral shoot elongation of all cultivars was more pronounced in September and October than in November, and it was influenced by cultivar, but not by the number of lateral shoots per plant (Table 1). The highest shoot length among the tested cultivars was measured in 'Primero Roso' throughout the growing period, whereas 'Cortez Candy' had the shortest shoots on 5 Nov. and 6 Dec. except compared with 'Christmas Star'.

The number of nodes on the lateral shoots also increased during the growing season, depending on cultivar (Table 1). In 'Christmas Feelings', the number of nodes increased by eight nodes from 6 Sept. to 5 Oct., after which the growth rate decreased. A different pattern was observed in 'Christmas Star', in which the highest increase of number of nodes was observed from 5 Nov. to 6 Dec. (seven nodes per shoot). In September and October, the numbers of nodes per shoot linearly decreased as the number of laterals per plant increased. However, after a sampling date on 5 Nov., these differences were not significant (Table 1).

In all cultivars except 'Cortez Candy', the diameter of the lateral shoot stem doubled from 6 Sept. to 5 Oct., after which the diameter growth slowed (Table 1$)$. At the last measurement (6 Dec.), lateral shoots of 'Primero Roso' were at least $2 \mathrm{~mm}$ wider than those of other cultivars, whose diameters ranged from $7.2 \mathrm{~mm}$ ('Christmas Feelings' and 'Cortez Candy') to $7.8 \mathrm{~mm}$ ('Marble Star'). A significant decrease of lateral shoot stem diameter as number of laterals per plant was increased from three to four, five, or six was observed on 5 Nov. and 6 Dec.

Kuehny et al. (2000) also found an inconsistent effect of the number of lateral shoots on poinsettia lateral stem area. They observed a higher stem area in plants with five laterals compared with those having six, seven, or eight laterals, but no difference between plants with four laterals and those with more laterals. The single-shoot growth was only slightly affected by the number of laterals per plant at the end of our experiment, except for the increase of lateral stem diameter. This indicates that there was no significant sink competition between the remaining shoots. In addition, the absence of a more pronounced growth of shoots in plants thinned to fewer laterals (i.e., three vs. six laterals) might suggest a lack of transfer of assimilates between remaining laterals, as was proposed for grapes (Naor et al., 2002).

Plant height increased in all cultivars from September to December over a range from $8 \mathrm{~cm}$ ('Cortez Candy' from 6 Sept. to 5 Oct.) to $13.5 \mathrm{~cm}$ ('Primero Roso' from 5 Nov. to 6 Dec.) per month (Table 2). During the entire growing period, 'Primero Roso' had the tallest plants of all cultivars, whereas from October through December, 'Cortez Candy' was among the shortest cultivars. The number of laterals affected plant height only on 5 Oct., when plant height linearly increased as the number of laterals increased, and the interaction between treatments was not significant (Table 2).

Differences in plant canopy diameter were observed among cultivars on all measurement dates (Table 2 ). In the period from September to December, the plant canopy diameter of 'Primero Rosso' increased from 36.4 to $71.8 \mathrm{~cm}$, reaching the highest values among the tested cultivars. There was no significant difference in plant canopy diameter between 'Cortez Candy' and 'Marble Star' during the growing period, whereas on 6 Dec., 'Christmas Star' was the narrowest. Only on 5 Oct., was the interaction of cultivar and number of laterals significant (Table 2, Fig. 1). The plant canopy diameter of 'Primero Roso' decreased as the number

Table 1. Lateral shoot length, number of nodes, and stem diameter of lateral shoot of five poinsettia cultivars thinned to three, four, five, or six lateral shoots.

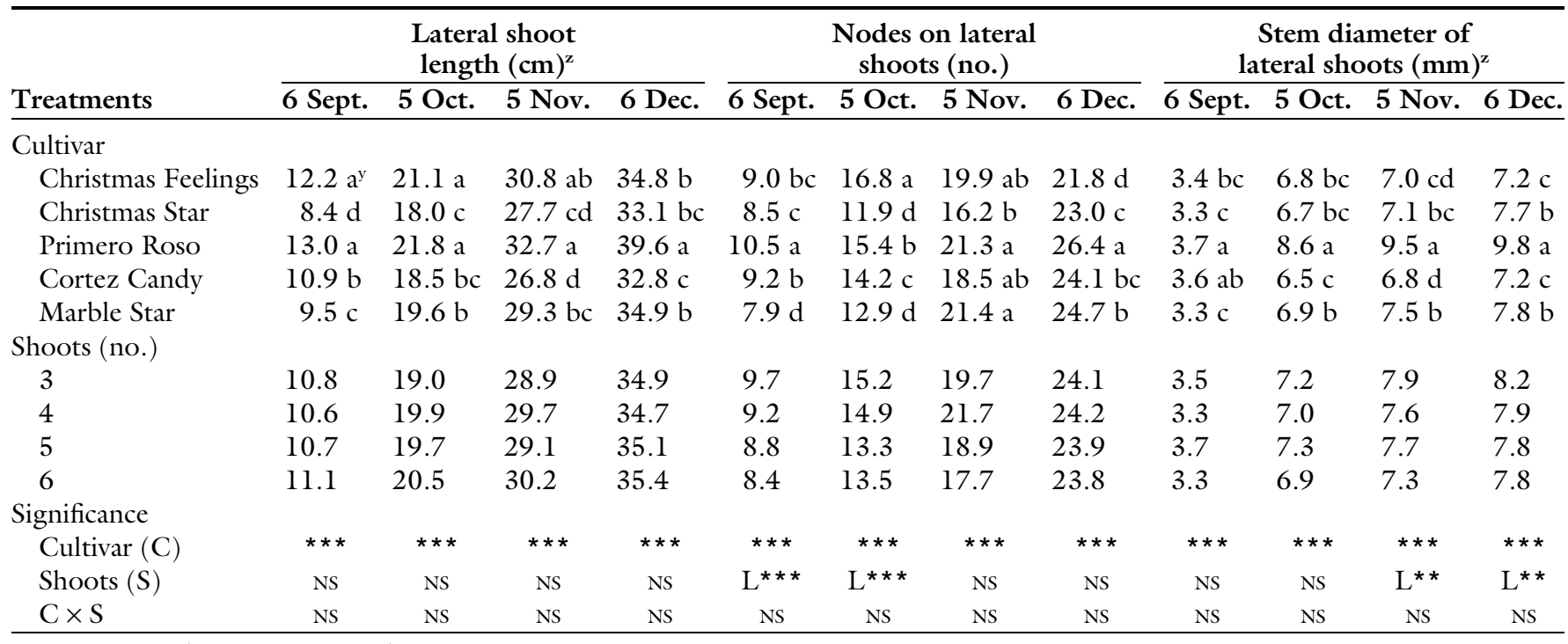

${ }^{\mathrm{z}} 1 \mathrm{~cm}=0.3937$ inch, $1 \mathrm{~mm}=0.0394$ inch.

${ }^{y}$ Means within columns for cultivar followed with different letters are significantly different at $P \leq 0.05$ by Fisher's protected least significant difference test.

$\mathrm{Ns}^{* *, * *, * \star *}$ Nonsignificant or significant at $P \leq 0.05,0.01,0.001$, respectively. Effects of number of lateral shoots were linear $(\mathrm{L})$ by polynomial analysis. 
Table 2. Plant height, and plant and main stem diameter of five poinsettia cultivars thinned to three, four, five, or six lateral shoots.

\begin{tabular}{|c|c|c|c|c|c|c|c|c|c|c|c|c|}
\hline \multirow[b]{2}{*}{ Treatments } & \multicolumn{4}{|c|}{ Plant ht $(\mathrm{cm})^{\mathrm{z}}$} & \multicolumn{4}{|c|}{ Plant canopy diameter $(\mathrm{cm})$} & \multicolumn{4}{|c|}{ Main stem diameter $(\mathrm{mm})^{\mathrm{z}}$} \\
\hline & 6 Sept. & 5 Oct. & 5 Nov. & 6 Dec. & 6 Sept. & 5 Oct. & 5 Nov. & $6 \mathrm{Dec}$. & 6 Sept. & 5 Oct. & 5 Nov. & 6 Dec. \\
\hline \multicolumn{13}{|l|}{ Cultivar } \\
\hline Christmas Star & $14.3 \mathrm{c}$ & $24.6 \mathrm{~b}$ & $34.7 \mathrm{~b}$ & $44.3 \mathrm{bc}$ & $27.9 \mathrm{~b}$ & $41.1 \mathrm{~d}$ & $53.7 \mathrm{~d}$ & $58.6 \mathrm{c}$ & $6.0 \mathrm{~b}$ & $7.0 \mathrm{c}$ & $8.2 \mathrm{~b}$ & $8.8 \mathrm{c}$ \\
\hline Primero Roso & $16.9 \mathrm{a}$ & $26.8 \mathrm{a}$ & $38.2 \mathrm{a}$ & $51.7 \mathrm{a}$ & $36.4 \mathrm{a}$ & $49.2 \mathrm{a}$ & $63.5 \mathrm{a}$ & $71.8 \mathrm{a}$ & $6.9 \mathrm{a}$ & $8.4 \mathrm{a}$ & $9.3 \mathrm{a}$ & $9.9 \mathrm{a}$ \\
\hline Cortez Candy & $14.9 \mathrm{c}$ & $22.9 \mathrm{c}$ & $31.8 \mathrm{c}$ & $42.7 \mathrm{c}$ & $28.9 \mathrm{~b}$ & $44.9 \mathrm{~b}$ & $58.9 \mathrm{~b}$ & $64.5 \mathrm{~b}$ & $6.3 \mathrm{~b}$ & $7.7 \mathrm{~b}$ & $8.2 \mathrm{~b}$ & $8.9 \mathrm{~b}$ \\
\hline 3 & 14.9 & 23.2 & 33.7 & 45.6 & 30.2 & 43.4 & 57.2 & 63.5 & 6.4 & 7.5 & 8.7 & 9.4 \\
\hline 4 & 15.4 & 25.1 & 35.6 & 45.3 & 30.2 & 45.3 & 57.5 & 64.3 & 6.3 & 7.7 & 8.5 & 9.1 \\
\hline 5 & 14.9 & 24.7 & 34.5 & 45.3 & 29.1 & 43.9 & 59.3 & 65.1 & 6.4 & 7.9 & 8.5 & 9.4 \\
\hline 6 & 15.0 & 25.2 & 35.6 & 46.3 & 30.8 & 44.6 & 58.2 & 64.9 & 6.2 & 7.7 & 8.4 & 9.2 \\
\hline \multicolumn{13}{|l|}{ Significance } \\
\hline
\end{tabular}

${ }^{\mathrm{z}} \mathrm{l} \mathrm{cm}=0.3937$ inch, $1 \mathrm{~mm}=0.0394$ inch.

${ }^{y}$ Means within columns for cultivar followed with different letters are significantly different at $P \leq 0.05$ by Fisher's protected least significant difference test.

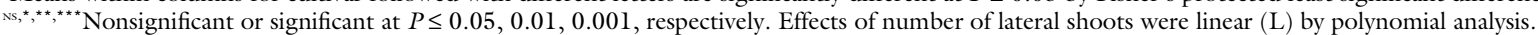

of lateral shoots per plant increased (Fig. 1). An opposite reaction was observed for 'Christmas Feeling', and there was no response in other cultivars. 'Cortez Candy' and 'Marble Star' had more horizontal plant architecture, with a ratio of plant height to diameter of 0.66 compared with more than 0.72 for other cultivars. Berghage et al. (1989) found that the method of pinching affected plant architecture, but according to our results, thinning appeared to have no effect.

The main stem diameter varied by cultivar throughout the growing season, with the widest main stem measured in 'Primero Rosso', whereas it was unaffected by the number of laterals (Table 2 ).

The leaf area ranged from 3014 $\mathrm{cm}^{2}$ in 'Christmas Star' to $5181 \mathrm{~cm}^{2}$ in 'Primero Roso', and it linearly increased as the number of laterals per plant increased (Table 3 ). The area of bracts was less affected by treatments and hence the differences between cultivars in total leaf area were mostly the result of leaf area growth. The ratio of leaf area to bracts area was cultivar dependent and ranged from 1.4 ('Christmas Star') to 2.9 ('Primero Roso').

The dry weight of leaves and bracts was more dependent on cultivar than on the number of laterals per plant (Table 3). Among the tested cultivars, the lowest weight of leaves was found in 'Christmas Star', but the same cultivar had among the highest

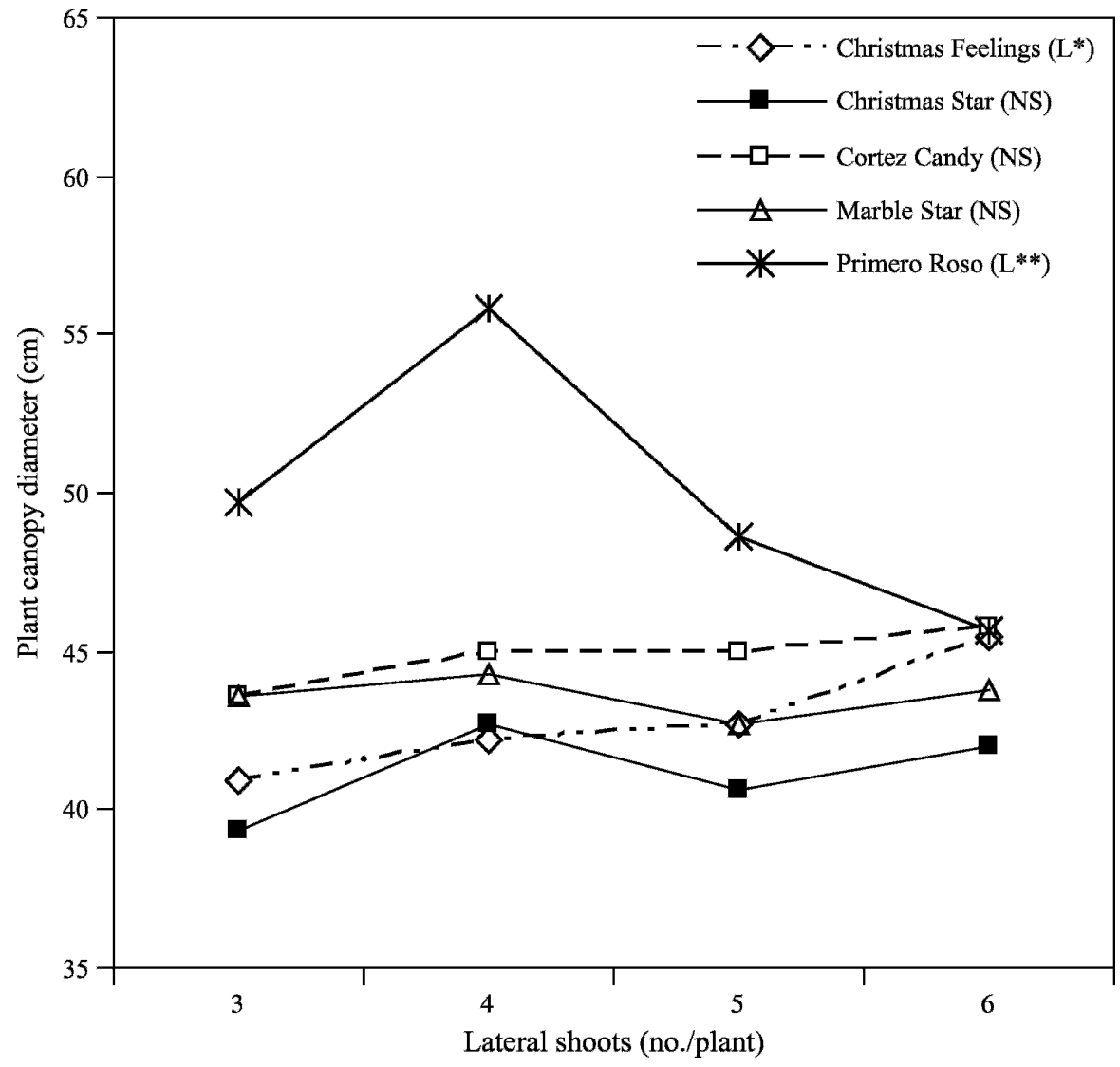

Fig. 1. Plant canopy diameter of five poinsettia cultivars thinned to three, four, five, or six lateral shoots measured on 5 Oct. Significance of number of lateral shoots is denoted for each cultivar in brackets and effects were nonsignificant (NS) or significant ${ }^{*}, * *$ by polynomial linear analysis $(\mathrm{L})$ at $P \leq 0.05,0.01$ respectively; $1 \mathrm{~cm}=0.3937$ inch.

weights of colored bracts. The weight of the main and lateral stems ranged from $5.5 \mathrm{~g}$ in 'Christmas Star' to $9.5 \mathrm{~g}$ in 'Primero Roso', and in addition the effect of cultivar, it increased linearly as number of laterals per plant increased. Similar effects of treatments were also found on total plant 
Table 3. The area of leaves and bracts, and dry weight (leaves, bracts, main stem with lateral shoots, and total) of five poinsettia cultivars thinned to three, four, five, or six lateral shoots.

\begin{tabular}{|c|c|c|c|c|c|c|c|}
\hline \multirow[b]{3}{*}{ Treatments } & \multirow{2}{*}{\multicolumn{3}{|c|}{ Area $\left(\mathrm{cm}^{2}\right)^{\mathrm{z}}$}} & \multicolumn{4}{|c|}{ Dry wt $(g)^{z}$} \\
\hline & & & & \multirow[b]{2}{*}{ Leaves } & \multirow{2}{*}{\multicolumn{2}{|c|}{$\begin{array}{c}\text { Main and } \\
\text { lateral stems }\end{array}$}} & \multirow[b]{2}{*}{ Total } \\
\hline & Leaves & Bracts & Total & & & & \\
\hline Cultivar & & & & & & & \\
\hline Christmas Feelings & $3787 c^{y}$ & 1788 & $5566 \mathrm{bc}$ & $11.6 \mathrm{c}$ & $3.7 \mathrm{~b}$ & $7.2 \mathrm{~b}$ & $22.5 \mathrm{~cd}$ \\
\hline Christmas Star & $3014 \mathrm{~d}$ & 2167 & $5182 \mathrm{c}$ & $9.3 \mathrm{~d}$ & $5.3 \mathrm{a}$ & $5.5 \mathrm{c}$ & $20.1 \mathrm{~d}$ \\
\hline Primero Roso & $5181 \mathrm{a}$ & 1813 & $6995 \mathrm{a}$ & $16.3 \mathrm{a}$ & $4.7 \mathrm{ab}$ & $9.5 \mathrm{a}$ & $30.5 \mathrm{a}$ \\
\hline \multicolumn{8}{|l|}{ Shoots (no.) } \\
\hline 3 & 3861 & 1904 & 5766 & 12.3 & 4.6 & 6.9 & 23.8 \\
\hline 4 & 4152 & 1829 & 5982 & 12.6 & 4.1 & 7.0 & 23.7 \\
\hline 5 & 4334 & 2138 & 6473 & 13.8 & 5.3 & 8.2 & 27.2 \\
\hline 6 & 4464 & 1846 & 6311 & 13.3 & 4.5 & 8.1 & 25.9 \\
\hline
\end{tabular}

${ }^{\mathrm{z}} 1 \mathrm{~cm}^{2}=0.1550$ inch $^{2}, 1 \mathrm{~g}=0.0353 \mathrm{oz}$.

${ }^{\mathrm{y}}$ Means within columns for cultivar followed with different letters are significantly different at $P \leq 0.05$ by Fisher's protected least significant difference test.

Ns, $,{ }^{* *},{ }^{* \star *}$ Nonsignificant or significant at $P \leq 0.05,0.01,0.001$, respectively. Effects of number of lateral shoots were linear (L) by polynomial analysis.

weight, although the plant part contributing most to total plant weight was the leaves.

Regardless of the lack of response of plant canopy diameter and height on number of laterals, the increased leaf area and dry weight of the main and lateral stems indicated that changes at the whole-plant level were present. Jovicich et al. (1999) found that leaves, stem, and total plant weight were similar in pepper (Capsicum annumm) plants pruned to two or four branches, but greater than in single-stem plants. In eucalyptus (Eucalyptus nitens) plants after severe pruning, more biomass is allocated to foliage at the expense of stem growth (Pinkard, 2002). Such an effect was not observed in the present study because the increased leaf area observed in plants with more laterals was not accompanied by increased leaf weight. In addition, the dry matter partitioning between leaves and stems in poinsettia was not changed by the increasing number of laterals. Thus, we can assume that increased leaf area simply represents the fact that these plants were left with more laterals. Heuvelink and Buiskool (1995) suggested that increased leaf area in tomato (Solanum lycopersicum) plants grown with more laterals provided more assimilates for vegetative growth. The degree of growth compensation after tissue loss (by pruning, herbivory, or some other cause) may depend on a number of variables, including tissue loss severity (Pinkard, 2002), resource availability, and the ability to allocate resources after damage (Fang et al., 2006). It appears that a weak response in growth, at the singleshoot or whole-plant level, could be expected in poinsettia plants thinned in the range from three to six laterals if they are grown under conditions like those used in the present study or under the absence of resource limitation (i.e., water and nutrients). Furthermore, thinning had no influence on the transition from the vegetative to generative phase in poinsettia because the bract area and dry weight were independent of the number of laterals.

All growth parameters, at the shoot and whole-plant levels, were more affected by cultivar than number of shoots. Because of intensive breeding work and the high number of available poinsettia cultivars, it is important to have insight into consumers' preferences in specific markets. The most distinctive attribute in our study was the bract color, because according to consumer evaluation,

Table 4. The rating of five poinsettia cultivars thinned to six lateral shoots by the following characteristics: color, plant height, canopy diameter, inflorescence number, ratio of leaves to bracts, general impression, and average rating.

\begin{tabular}{|c|c|c|c|c|c|c|c|}
\hline Cultivar & Color & $\begin{array}{c}\text { Plant } \\
\text { height }\end{array}$ & $\begin{array}{c}\text { Plant canopy } \\
\text { diameter }\end{array}$ & $\begin{array}{c}\text { Inflorescence } \\
\text { no. }\end{array}$ & $\begin{array}{c}\text { Leaves: Bracts } \\
\text { (ratio) }\end{array}$ & $\begin{array}{c}\text { General } \\
\text { impression }\end{array}$ & $\begin{array}{c}\text { Average } \\
\text { rating }\end{array}$ \\
\hline \multicolumn{8}{|c|}{$(1 \text { to } 5 \text { scale })^{\mathrm{z}}$} \\
\hline Christmas Feelings & $4.3 \mathrm{a}$ & 4.0 & 3.8 & 4.1 & 4.0 & 3.9 & 4.0 \\
\hline Primero Roso & $4.5 \mathrm{a}$ & 4.3 & 3.8 & 4.1 & 4.2 & 4.0 & 4.1 \\
\hline Cortez Candy & $3.3 \mathrm{~b}$ & 4.0 & 4.1 & 4.1 & 4.1 & 3.7 & 3.9 \\
\hline
\end{tabular}

${ }^{\mathrm{z}} 1$ = not satisfactory, $5=$ excellent.

'Rating was compared using Fisher's protected least significant difference test, a column followed with different letters are significantly different at $P \leq 0.05$.

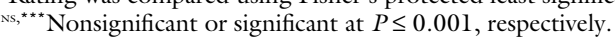


significant differences among cultivars were observed only for that trait (Table 4). When evaluators were asked which of the offered cultivars they would buy, $30 \%$ of them chose 'Christmas Star'; 20\% chose 'Christmas Feelings'; 20\% chose 'Primero Roso'; 30\% chose 'Marble Star'; and only $10 \%$ chose 'Cortez Candy'. According to rating for colors and buying preferences $(60 \%$ of evaluators preferred red cultivars) it appears that the color is a highly important characteristic. In a more comprehensive consumer research study, Behe et al. (1997) found that the market prefers red-colored poinsettia cultivars.

Рот size (Expt. 2). The plant height, main stem diameter, and length of lateral shoot measured at 4-week intervals from September to December were unaffected by pot size (data not shown). Over the entire growing period, plant canopy diameter linearly increased with the increase in pot diameter (Fig. 2A). Because a similar effect was not observed for plant height, it appears that pot size affected the architecture of the plant by changing the plant heightto-diameter ratio. The lateral stem diameter and the number of nodes per lateral shoot also increased as pot size increased from 5 Oct. to 4 Dec. (Fig. 2, B and C). However, the absence of such an effect on lateral shoot length suggests that the increase in pot size did not promote greater shoot growth.

The increase of final plant height and the weight of leaves, stems, and total plant (from $6 \%$ to $10 \%$ ) in 18 $\mathrm{cm}$-diameter pots compared with 13$\mathrm{cm}$-diameter pots was nonsignificant (Table 5). Leaf and bract area were only marginally changed with pot size, as well.

In addition to the responsiveness of plant species, it seems that pot volume could differently affect growth parameters. In this study, only plant canopy diameter, stem diameter, and number of nodes were increased by increasing pot volume. In hydrangea (Hydrangea macrophylla) and petunia (Petunia Xhybrida) plants, shoot and root dry weight were increased by increasing pot volume, whereas there was no effect on the number of nodes (Haver and Schuch, 2001; Yeh and Chiang, 2001).
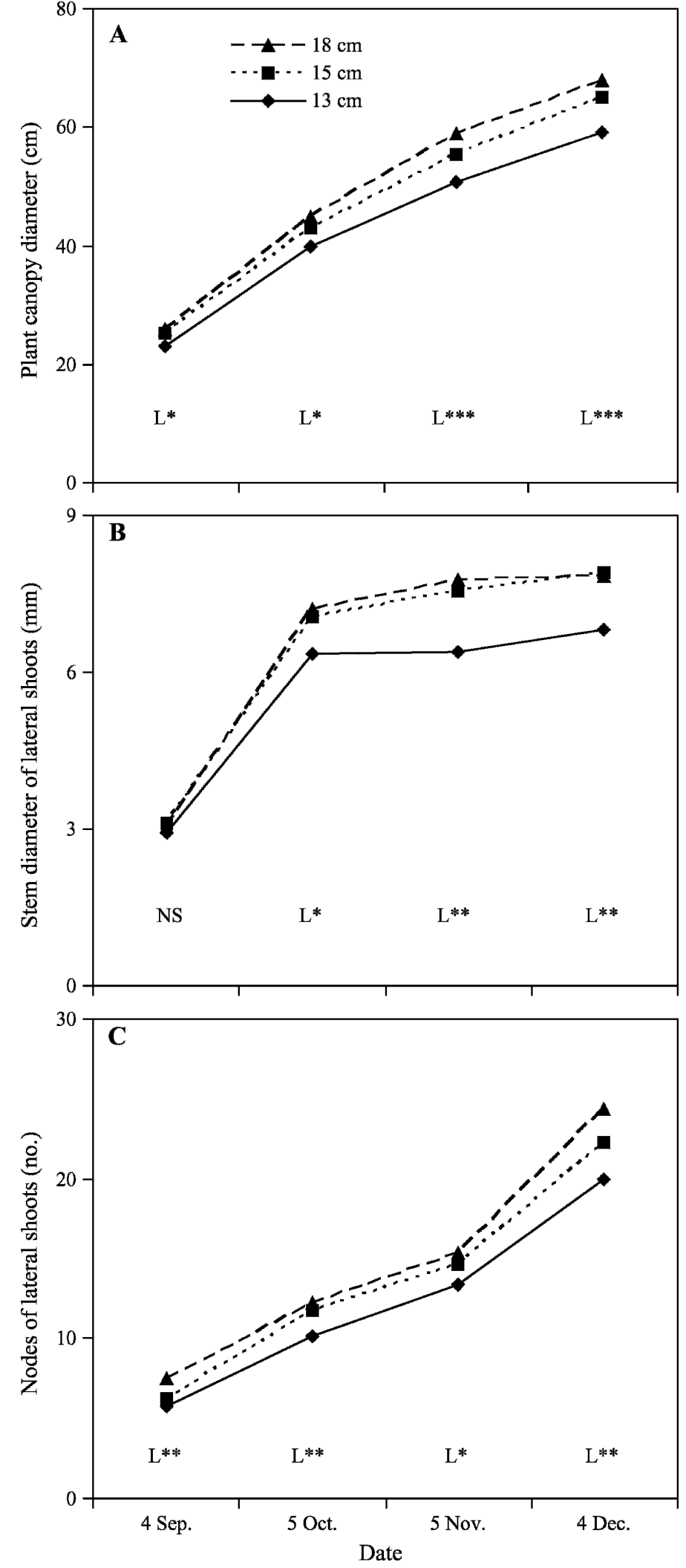

Fig. 2. Effect of pot size (13-, 15-, or 18-cm diameter) on plant canopy diameter (A), stem diameter of lateral shoot (B), and number of nodes (C) of poinsettia 'Christmas Star'. The effects of pot size for each date were nonsignificant (NS) or significant ${ }^{*}, * *, * *$ by polynomial linear analysis $(\mathrm{L})$ at $P \leq 0.05,0.01,0.001$, respectively; $1 \mathrm{~cm}=0.3937 \mathrm{inch}, 1 \mathrm{~mm}=0.0394$ inch. 
Table 5. Effects of pot size $(13-, 15-$, or $18-\mathrm{cm}$ diameter $)$ on plant height, leaves, and bracts area, and dry weight of poinsettia 'Christmas Star' on 5 Dec.

\begin{tabular}{|c|c|c|c|c|c|c|c|}
\hline \multirow{3}{*}{$\begin{array}{l}\text { Pot diameter } \\
(\mathrm{cm})^{\mathrm{z}}\end{array}$} & \multirow{3}{*}{$\begin{array}{c}\text { Plant } \\
\text { ht }(\mathrm{cm})\end{array}$} & \multirow{2}{*}{\multicolumn{2}{|c|}{ Area $\left(\mathrm{cm}^{2}\right)^{\mathrm{z}}$}} & \multicolumn{4}{|c|}{ Dry wt $(g)^{z}$} \\
\hline & & & & \multirow[b]{2}{*}{ Leaves } & \multirow[b]{2}{*}{ Bracts } & \multirow{2}{*}{$\begin{array}{c}\text { Main and } \\
\text { lateral stems }\end{array}$} & \multirow[b]{2}{*}{ Total } \\
\hline & & Leaves & Bracts & & & & \\
\hline 13 & 48.5 & 3587 & 2576 & 9.6 & 6.1 & 6.9 & 22.6 \\
\hline 15 & 49.9 & 3695 & 2565 & 10.3 & 6.4 & 6.6 & 23.3 \\
\hline 18 & 51.8 & 3504 & 2386 & 10.6 & 6.0 & 7.3 & 24.0 \\
\hline Significance $^{y}$ & NS & NS & NS & NS & NS & NS & NS \\
\hline
\end{tabular}

${ }^{\mathrm{z}} 1 \mathrm{~cm}=0.3937$ inch, $1 \mathrm{~cm}^{2}=0.1550$ inch $^{2}, \mathrm{l} \mathrm{g}=0.0353 \mathrm{oz}$.

yEffects were nonsignificant (NS) at $P \leq 0.05$

The beneficial effect of pot size on the aboveground plant weight and leaf area of poinsettia plants was not found in this experiment, possibly because the growth period was not long enough to impose the plants in smaller pots (13-cm diameter) to root restriction.

\section{Conclusions}

Differences in growth parameters were observed among the cultivars tested. 'Primero Roso' was the most vigorous cultivar over the entire growing season, whereas at the end of the experiment, 'Christmas Star' was the least developed cultivar in the most of the observed parameters. Thinning had little effect on most of the growth parameters. At the singleshoot level, plants with more laterals had a reduced number of nodes at the beginning of the season and a decreased stem diameter in the last two measurements (on 5 Nov. and 6 Dec.). At the end of experiment, plants with more lateral shoots had greater leaf area and increased dry weight of stems and total plant weight. Because growth response to thinning was observed for a few growth parameters and with a small change in magnitude, according to our results, it appears that there is not much justification to recommend shoot thinning in potted poinsettia production. This procedure did not substantially improve growth or quality of the product that may compensate for the increased cost of labor needed for a thinning operation. The most distinctive attribute of poinsettia cultivars was the color of bracts, with $60 \%$ of evaluators preferring red cultivars.

The effect of pot size on wholeplant and single-shoot growth of poinsettia 'Christmas Star' depended on the observed vegetative growth parameter. An increase in pot size resulted in an increase of total plant canopy diameter, stem diameter, and number of nodes on lateral shoots. There were no other benefits on vegetative growth that could justify the use of pots larger than $13 \mathrm{~cm}$ in diameter for a poinsettia crop established at the beginning of September and grown under conditions like those in this study.

\section{Literature cited}

Behe, B.K., P.B. Redman, and J.M. Dole. 1997. Consumers prefer red poinsettia cultivars. HortTechnology 7:438441.

Berghage, R.D., R.D. Heins, M. Karlsson, J.E. Erwin, and W. Carlson. 1989 Pinching technique influences lateral shoot development in poinsettia. J. Amer. Soc. Hort. Sci. 114:909-914.

Black, R.J. and R.K. Schoellhorn. 2002. Poinsettias for Florida, indoors and outdoors. University of Florida, Institute of Food and Agricultural Sciences, Ext. Serv. Bul. CIR628. 28 May 2007. <http:// edis.ifas.ufl.edu/MG352/>.

Clifford, S.C., E.S. Runkle, F.A. Langton, A. Mead, S.A. Foster, S. Pearson, and R.D. Heins. 2004. Height control of poinsettia using photoselective filters. HortScience 39:383-387.

Cox, D.A. 2000. Fertilizer recommendations for poinsettias. 5 July 2007. $<\mathrm{http}$ ://www.umass.edu/umext/flori culture/fact_sheets/specific_crops/ poinfert.html>.

Ecke, P., Jr. and O.A. Matkin. 1971. The poinsettia manual. lst ed. Paul Ecke Poinsettias, Encinitas, CA.

Fang, X.W., X.Z. Wang, H. Li, K. Chen, and G. Wang. 2006. Responses of Caragana korshinskii to different aboveground shoot removal: Combining defense and tolerance strategies. Ann. Bot. (Lond.) 98:203-211.

Faust, J.E. and R.D. Heins. 1996. Axillary bud development of poinset- tia 'Eckespoint Lilo' and 'Eckespoint Red Sails' (Euphorbia pulcherrima Willd.) is inhibited by high temperatures. J. Amer. Soc. Hort. Sci. 121: 920-926.

Fisher, P.R., R.D. Heins, and J.H. Lieth. 1996. Quantifying the relationship between phases of stem elongation and flower initiation in poinsettia. J. Amer. Soc. Hort. Sci. 121:686-693.

Haver, D. and U. Schuch. 2001. Influence of root restriction and ethylene exposure on apical dominance of petunia (Petunia $\times$ bybrida Hort. Vilm-Andr.). Plant Growth Regulat. 35:187-196.

Heuvelink, E. and R.P.M. Buiskool. 1995. Influence of sink-source interaction on dry matter production in tomato. Ann. Bot. (Lond.) 75:381-389.

Jovicich, E., D.J. Cantliffe, and G.J. Hochmuth. 1999. Plant density and shoot pruning on fruit yield and quality of a summer greenhouse sweet pepper crop in north central Florida, p. 184190. In: K.D. Batal (ed.). 28th Natl. Agr. Plastics Congr. Proc. Amer. Soc. Plasticulture, Tallahassee, FL, 19-22 May 1999. American Society for Plasticulture, State College, PA.

Kannangara, C.G. and M. Hansson. 1998. Arrest of chlorophyll accumulation prior to anthocyanin formation in Euphorbia pulcherrima. Plant Physiol. Biochem. 36:843-848.

Kuehny, J.S., P.C. Branch, and P.W. Adams. 2000. Stem strength of poinsettia. Acta Hort. 515:257-264.

Lee, I.M., M. Klopmeyer, I.M. Bartoszyk, D.E. Gundersen-Rindal, T.S. Chou, K.L. Thomson, and R. Eisenreich. 1997. Phytoplasma-induced free-branching in commercial poinsettia cultivars. Nat. Biotechnol. 15: 178-182.

Naor, A., Y. Gal, and B. Bravdo. 2002. Shoot and cluster thinning influence vegetative growth, fruit yield, and wine quality of 'Sauvignon blanc' grapevines J. Amer. Soc. Hort. Sci. 127:628-634.

Nesmith, D.S. and J.R. Duval. 1998. The effect of container size. HortTechnology 8:495-498.

Pallez, L.C., J.M. Dole, and B.E. Whipker. 2002. Production and postproduction studies with potted sunflowers. HortTechnology 12:206-210.

Pinkard, E.A. 2002. Effects of pattern and severity of pruning on growth and branch development of pre-canopy closure Eucalyptus nitens. For. Ecol. Manage. 57:217-230. 
Sonneveld, S. 1989. A method for calculating the composition of nutrient solutions for soilless cultures. 3rd translated ed. Glasshouse Crops Research Station, Naaldwijk, The Netherlands.

Thomas, D.S., K.D. Montagu, and J.P. Conroy. 2006. Effects of leaf and branch removal on carbon assimilation and stem wood density of Eucalyptus grandis seedlings. Trees-Structure Function 20: $725-733$.

van Iersel, M. 1997. Root restriction effects on growth and development of salvia ( Salvia splendens). HortScience 32:1186-1190.
Yeh, D.M. and H.H. Chiang. 2001. Growth and flower initiation in hydrangea as affected by root restriction and defoliation. Scientia Hort. 91:123-132. 